\title{
ON SPECIALITIES OF THE EГK'ҮKAIOГ ПАILE'IA'S USE IN GREEK AND ROMAN ANCIENT THOUGHT
}

\section{Zotova ${ }^{1}$}

\author{
DOI: http://doi.org/10.15350/L_26/8/07
}

\begin{abstract}
Материал статьи подготовлен в рамках проекта «Философская пропе-

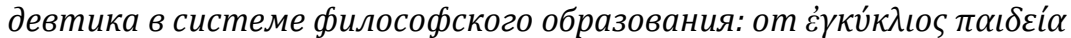
к энциклопедии философских наук», грант РГНФ № №16-03-50171
\end{abstract}

\section{Abstract}

The article discusses the specialities of the use, the origination and the

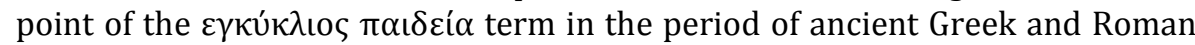
thought. It turns out that, on the one hand, this term is understood as the necessary and nature-aligned propedeutics or the circular formation of a soul, which raises it to the divine order. On the other hand, the spirit of the antiquity does

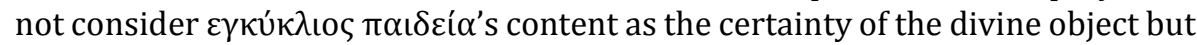
only as its instrument. Therefore, the logic of the educational process of a soul and its connection with the educational content and wisdom as its absolute goal remains unclear.

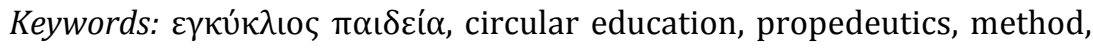
soul.

В настоящей статье ставится цель приоткрыть в пределах грекоримской античной мысли подводную часть «айсберга», с которым можно

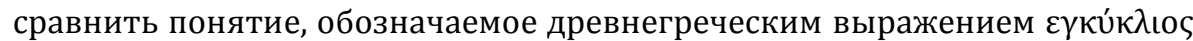
$\pi \alpha \iota \delta \varepsilon \dot{\alpha} \alpha$, и тем самым показать, что употребляемый в наши дни термин enkyklopaideia (энциклопедия), образованный от него, вне целостного культурно-исторического и философского рассмотрения оказывается лишь его «верхушкой».

Данное исследование стоит начать с вопроса о том, для чего

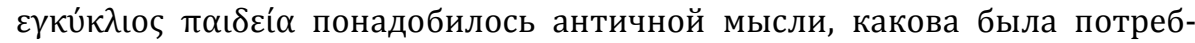
ность, породившая необходимость употребить его. В этой связи стоит об-

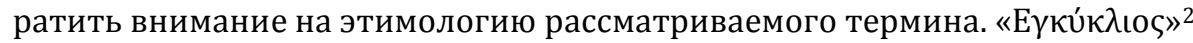
значит «круглый», «шарообразный», «циклический», «общий», «общеобразовательный», «повседневный», «обычный» и т.д. Разброс переводов слова

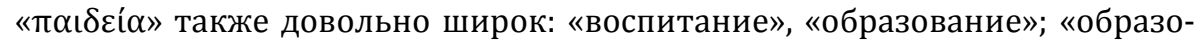
sity, Russia.

1Irina Zotova, Candidate of Philosophical Sciences, Lecturer, Kuban State Univer-

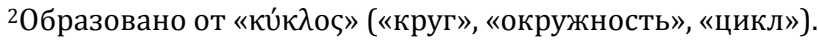


ванность», «просвещение», «культура», «наставление», «наказание», «дис-

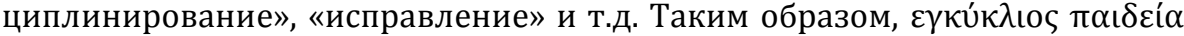
чаще всего переводится как «общее или среднее образование», либо как «общая или всесторонняя культура».

Аристотель, отмечает И. Адо, использует прилагательное

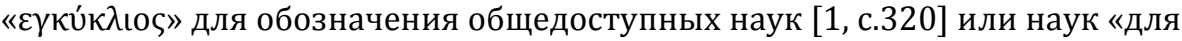
широкого круга» [4, с. 58]. Р.Л. Фоулер утверждает, что в IV в. до н.э. в этом

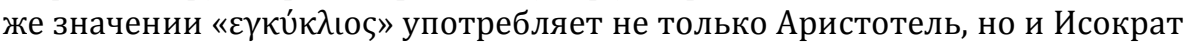

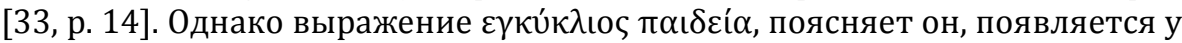
греческих авторов лишь в I в. до н.э., в частности, у Дионисия Галикарнасского и Диодора [Ibid]. Последний же, согласно Адо, использует его для характеристики того общераспространенного образования, которого не имел вождь лузитан, пастух Вириаф, научившийся тем не менее «в ходе постижения практических дел» всему тому, что помогло ему в одной из войн против Рима отдавать эффективные распоряжения [11].

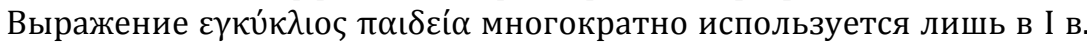
н.э. Адо уточняет, что особенно часто оно встречается у Филона Александрийского, «который посвятил этой теме целый трактат, озаглавленный “О знакомстве души с подготовительными знаниями” (De congressu)» [1, c.343]. При этом, по ее предположению, ряд авторов императорской эпохи (Стобей, Диоген Лаэрций, Афиней) вкладывают данное понятие в уста своих предшественников (Зенона, Крантора, Аристона, Аристипп и др.), употребляя его как «терминологию своего времени» [1, с.320] в стремлении резюмировать и определить их мысль. Но не значит ли это, что лишь в период позднеантичной мысли происходит усвоение некоего предмета,

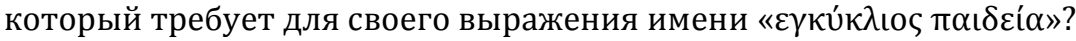

К.Р. Симон полагает, будто римляне, не до конца поняли того, что

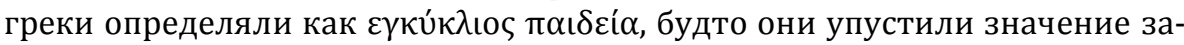
вершенности знаний или полноту образования и якобы внесли в определение данного понятия идею иерархии наук, заменив его латинскими терминами orbis doctrinae, orbis doctrinarum, orbis disciplinarum [24]. Вместе с тем И. Адо доказывает обратное тому, о чем пишет К.Р. Симон, а именно, что как раз латинские авторы, не отрицая принципа иерархии, начинают понимать под $\varepsilon \gamma \kappa u ́ \kappa \lambda เ o \zeta ~ \pi \alpha ı \varepsilon \varepsilon i ́ \alpha$ единство и круговое взаимопроникновение наук ${ }^{1}$.

Данный вывод становится еще более очевидным, если проследить историю развития античной идеи т $\alpha \delta \varepsilon i ́ \alpha$, которую тщательнейшим образом исследует В. Йегер. Он обращается к тому эпитету, который когда-то Г.В.Ф. Гегель дал пути развития духа во всемирном масштабе, назвав его «окольным». В этой связи Йегер подчеркивает, что натурфилософия должна была стать для греков приоритетной, они должны были начать с исследования закономерностей внешнего порядка, чтобы, воспитываясь

1Более подробно см.: Адо И. Свободные искусства и философия в античной мысли. М.: Греко-латинский кабинет Ю.А. Шичалина, 2002. С. 335-343. 
ими, спроектировать их на устройство души, открыв в ней аналогичные закономерности и достигнув, таким образом, «объективного воззрения на внутренний космос» [12, с.196]. В итоге, продолжает Йегер, это открытие и делает возможным «новое воспитание человека на основе философского познания, которое как цель ставил перед собой Платон» [Там же]. Поэтому и смысл различения натурфилософии и философии духа, подчеркивает он, может быть усмотрен «именно с точки зрения истории образования» [Там же]. А значит и интерес грека к природе человека, удовлетворяемый им сперва через познание телесности и через стремление достичь в ней иде-

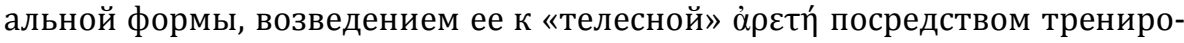
вок тела, в конце концов, должен был возвысить его до поиска умственной доблести (бофí $\alpha)$ как того, что расширяет его представления о человеческом идеале и дает ему основание осуществлять критику человеческой жизни в целом [Там же, с. 219].

Итак, греческая философия начинает с вопроса о природе вообще именно для того, чтобы поставить вопрос о природе человека, в частности, о том, что является его образом или мерой его бытия, которая есть у каждой вещи. Вопрошание об имманентном природном порядке, о всепроникающей мировой закономерности и норме открывает основания для постановки вопроса об образовании человека, ведь греческий мыслитель не удовлетворяется лишь созерцанием этого образа, но начинает рассматривать его как образец или идеал, как должное, которое требует обнаружения соответствия себе. В. Йегер прослеживает историю постановки данного вопроса, показывая, например, как уже в стихах Ксенофана «умственная доблесть» начинает превалировать над «телесной». А размышления Парменида о невозможности логического противоречия, продолжает он, открывает «принудительность» мысли и вместе с этим то долженствование, которое позволяет очертить путь следования ей [Там же, с. 221]. Открытие чистого мышления как необходимости, подмечает Йегер, становится открытием необходимости возвышения души от чувственного восприятия и мнения до подлинного понимания истины или открытием необходимости пути следования истине, то есть открытием необходимости метода познания: «Образ правильного пути (обós) исследования повторяется вновь и вновь, и, хотя это только образ, он обретает практически терминологическое звучание, особенно, в противопоставлении друг другу правильного и ошибочного пути, где путь приближается к значению "метода"» [Там же, с. 222].

Но постижение необходимости правильного пути («многовестного пути Божества» указывает на того, кто идет по нему, кого Парменид называет «знающим мужем», демонстрируя тем самым образец или норматив подлинного жизненного поведения. Вместе с тем необходимо отметить, что «знающий муж» Парменида не идет сам по этому пути [28, с. 286]. Его несут «сверхпроницательные кони», а Коры (юные Девы) - сопровождают

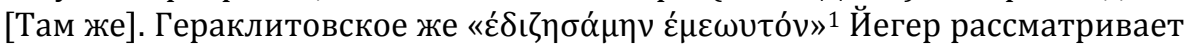

1"Я исследовал самого себя". 
как «открытие нового мира познания через обращение души к себе самой» $[12$, c.225], что также можно интерпретировать и как открытие ею самой себя в качестве источника самоподдержки и собственного развития. Ряд комментаторов Гераклита, ставящих акцент на его самообразовании, дают нам основания для такой интерпретации. Они подчеркивают, что мыслитель не был чьим-то учеником, не имел учителей и, являясь самоучкой, «выпытал» самого себя или узнал все из себя самого. Таким образом, не только то, к чему парменидовского «знающего мужа» ведут внешние для него силы, гераклитовский находит в себе, но и эти силы он черпает из самого себя как собственный имманентный закон [28, с. 194-195].

Йегер уверенно утверждает о том, что из «пристрастия грека к форме» проистекает «норма душеводительства» как основа воспитания или «сознательного формообразования». Отсюда и греческий гуманизм или, поясняет он, подлинная греческая пайдейя - «приведение человека к его истинной форме, форме человека как такового» [12, с. 23], понятое римлянами как humanitas. В работе «Гуманизм и теология» он повторяет свою мысль: «Рaideia... являлась историческим корнем того, что Цицерон восхвалял как humanitas греков» [34, p. 40].

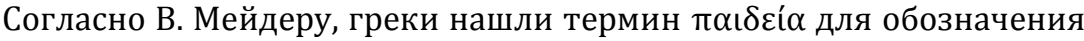
образования как «родового признака человечества» [15, с. 422]. А.И. Марру высказывает аналогичную точку зрения, однако уточняет: $\pi \alpha \iota \varepsilon \varepsilon i ́ \alpha-$ это образование взрослого человека или человека вообще, несмотря на то, что данное слово образовано от паı (ребенок). Поэтому и понимать данный термин необходимо как “... “обращение, которое показано ребенку”, чтобы сделать из него человека». Именно римляне Варрон и Цицерон, продолжает Марру, сумели уловить это и найти удачный латинский эквивалент греческому терминуㅁ.

Таким образом, в первую очередь, $\pi \alpha \iota \varepsilon \varepsilon i \alpha$ обозначает становление и взросление человека, развитие человеческой природы, путь ее формообразования. В то же время грек не останавливается лишь на осознании идеи этого пути как того долженствования, которое открывается постигаемой им идеальной формой. Поэтому т $\alpha \delta \varepsilon i ́ \alpha$ становится его образовательной программой, несмотря на то, что и ее назначение, и содержание, и способы реализации постоянно уточняются. В этой связи обращает на себя внимание прагматическая идея софистического образования, а также программа ее реализации, которые должны были составить необходимый момент в «окольности» развития античного духа, как раз ведущий его к открытию принципа цикличности в образовательном процессе. Действительно, ведь если продумать релятивистские взгляды софистов, то мы обнаружим, что они направлены против внешне навязанного непостижимого порядка. Но софисты не выступают против порядка как такового и вытекающих из

1Более подробно см.: Марру А.-И. История воспитания в античности (Греция). М.: Греко-латинский кабинет Ю.А. Шичалина, 1998. С. 142, 306, 316; Йегер В. Пайдейя. Воспитание античного грека. Том 1. М.: Греко-латинский кабинет Ю.А. Шичалина, 1997. С. 22. 
него законов, они иначе понимают основания их данности человеку. Таким основанием для них является не природа вообще, а внутренняя природа человека, в которой содержится все то, благодаря чему он естественным для себя образом познает принципы правильного жизнеустройства и должного пути, а также постигает, что может создавать самого себя. Именно этим открытием софисты дают толчок развитию гуманистических идеалов античности, о чем говорят абсолютно все крупные исследователи истории античного образования, параллельно рассматривающие происхождение уже упомянутого римского понятия humanitas. В этой же связи, интерпретируя известный принцип Протагора, Йегер подчеркивает, что вместе с ним получает выражение и то, что мы связываем со словом «куль-

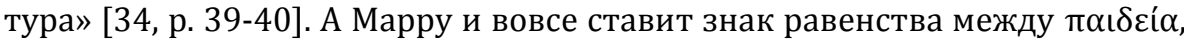

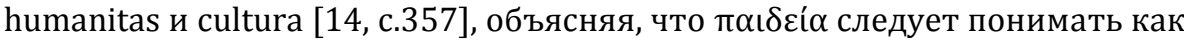
систему заботы и поддержки ребенка («возделывания»), но необходимую не столько для роста его организма (такому значению скорее соответствует греческое трє́ $\varphi \omega$ - «выкармливать», «питать», «воспитывать»), сколько для интеллектуального и духовного развития в ребенке человека, то есть для воплощения человечности как внутренне заложенной в нем идеи и предназначения [35, p.552]. В этом заключена глубочайшая идея античного образования, постигая которую мы постигаем и то, что образовательный процесс невозможно понимать линейно.

Так, описывая ту систему познания, которая могла бы «увлечь душу от становления к бытию» [19, с.303], Платон объясняет, что изучение различных наук должно привести к «установлению их общности и родства» [Там же, с.315], должно показать их связь. И хотя он называет эти науки вступлением к подлинному познанию, тем не менее рассматривает их как знание только в том случае, если постигается их единство: «А кто не в состоянии привести разумный довод или его воспринять, тот никогда не будет знать ничего из необходимых, по нашему мнению, знаний» [Там же]. Сами же по себе, продолжает Платон, они не представляют собой подлин-

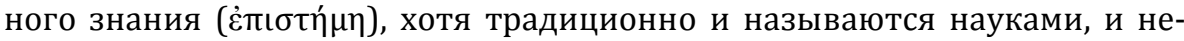
смотря на то, что по степени отчетливости их содержание превосходит мнение, все же «...им всего лишь снится бытие, а наяву им невозможно его увидеть, пока они, пользуясь своими предположениями, будут сохранять их незыблемыми и не отдавать себе в них отчета» [Там же, с.317].

Таким образом, с одной стороны, душа нуждается в них как в ступенях для восхождения к подлинной науке, с другой же, она не знает их истины до тех пор, пока не откроет ее для себя: «У кого началом служит то, чего он не знает, а заключение и середина состоят из того, что нельзя сплести воедино, может ли подобного рода несогласованность когда-либо стать знанием?» [Там же]. Иными словами, путь к истине лежит через изучение особенных предметов, и поначалу душа будет верить, будто располагает знанием о них. Однако лишь тогда, когда она восходит к их сущности посредством разума, ей открывается, что «знание», которое вело ее к ней, само проясняется, то есть только в этот момент оказывается знанием. Таким образом, мы имеем дело с парадоксом кругового движения души, 
которая должна усмотреть в нем тождественное, когда «...одно и то же мы видим и как единое, и как бесконечное множество» [Там же, с.307].

С этой точки зрения утверждения софистов о том, что добродетели можно научить, из которого вообще вытекает тот популярный вывод, согласно которому педагогический результат можно просчитать и на котором основана педагогика проектирования человека, полностью преодолевается. Образовательный процесс, совершаемый душей под руководством софиста, осуществляется линейно. Софист всегда обещает научить, он гарантирует результат, поэтому он и берет плату за свой труд. И хотя заслуга софистов в том, что после них мы в принципе уже не можем не смотреть на образование как на процесс по сути своей гуманистичный, совершающийся не в силу некоей независимой от воли человека предопределенности или власти над ним его рода, но на основе его собственного выбора и его внутренней природной предрасположенности, без которых он в принципе не мог бы и состояться, тем не менее страх софистов перед теорией ограничил их выводы лишь констатацией некоей связи между натренированной для осуществления политической добродетели душей и самой этой добродетелью. Иными словами, софисты не объясняют того, как полученное человеком образование, сформировавшее у него те или иные гражданские и политические умения, развившее рассудок, сделавшее его ум острым, позволяет непосредственно перейти к познанию всеобщей государственной добродетели. Принцип общности такого образования оказывается формальным, такое образование является абстрактно всеобщим, то есть как раз и незавершенным. Если содержание всего образовательного цикла необходимо не само по себе, а лишь для того, чтобы сделать из души некую способность или снабдить ее инструментом, с помощью которого она якобы будет подготовлена к успешной жизни в государстве, то такая душа скорее станет похожей на пустой сосуд, у которого хотя и имеется присущая ему субъектность как потенция быть заполненным, однако сам по себе он еще не способен наполнить себя облагораживающим его нутро содержанием. Как оказывается, и учитель, сосредоточенный лишь на выработке у своего подопечного навыков политического мастерства, далек от того, чтобы помочь ему в этом. Вот почему, рассуждает Сократ, лучшие натуры или те, кто благодаря своим способностям лучше остальных предрасположены к восприятию духовного содержания, легко могут быть испорчены, оказавшись в дурных условиях и под дурным влиянием. Поэтому, продолжает он, та натура, которая «...предназначена для благороднейшего занятия» [Там же, с.275], то есть для философии, которая сумела сохранить себя, реализовав эту предрасположенность, редкость.

Данными размышлениями Сократ в полной мере раскрывает собственную идею образования человека - стать подлинным философом, который сумел реализовать своим образом жизни свой эйдос, несмотря на те сложности взаимоотношений с государством и тот антагонизм с толпой, которые ему пришлось пережить. В отличие от софистов, полагавших, будто о благе государства может рассуждать каждый, Сократ считает, что такое знание недоступно толпе, поскольку она располагает лишь мнением: 
«...возможно ли, чтобы толпа допускала и признавала существование красоты самой по себе, а не многих красивых вещей или самой сущности каждой вещи, а не множества отдельных вещей?» [Там же, с.273]. И если софист приспосабливается к толпе, то философская душа обладает абсолютно иным качеством - она неспособна отдать предпочтение некоему особенному мнению, поскольку ее отличают «...решительное неприятие какой бы то ни было лжи, ненависть к ней и любовь к истине» [Там же, с.263]. Вот почему теперь оказывается необходимым дать теоретическое обоснование уже не тому, какие отдельные черты характера или отдельные навыки и умения необходимо воспитывать в человеке, чтобы он мог бесконфликтно существовать в государстве, но, напротив, как раз тому целокупному и пронизывающему всю душу образованию, которое делает ее мысленный взор всеохватывающим, благодаря чему она способна обозревать «целокупное время и бытие» [Там же, с.264] и потому возвышаться над всеми противоречиями земной жизни, глядя на них лишь как на побочный эффект своего стремления оставаться правдивой, только и делающее ее поистине счастливой.

Можно ли в этой связи вести речь о каком-либо ином воспитании, нежели о воспитании философа? Воспитание софистов является общим, поскольку оно может быть доступно многим и, кроме того, направлено на общедоступный политический идеал, благодаря чему его содержание приобретает, пусть и формальную, но все же упорядоченность. Но образование философа следует считать элитарным и недоступным большинству. Продумав то, в какой степени формальная всеобщность софистического образования необходима, можно выяснить, что как раз такой всеобщности недостает единства. Она изменчива по своему содержанию, поскольку привязана к изменчивому этосу толпы. Идея образования философа, напротив, определена как тождество приобретаемой душей формы и усваиваемого ею содержания. Вот почему, описывая программу воспитания философа, а именно то, чем потенциальный философ должен заниматься и с какими предметами должен знакомиться, Платон ставит акцент на завершении этого движения усвоением идеи всего многообразия содержания, с которым душа имеет дело. Поэтому не приземленность его идеала и доступность большинству, а то, что им охвачена вся душа целиком, все ее силы и способности, то, что каждый особенный момент восхождения к нему полагается не сам по себе, не произвольно и случайно, а определен единым принципом, вырастающим из единства ее внутренних сил, - все это делает такое образование подлинно всеобщим и завершенным. То, что представляет собой частное и особенное, - то, к чему приступает душа, - рассматривается как уже завершенное по своей идее и, напротив, то, что открывается в конце, постигается как подлинное начало. Отсюда теория припоминания и учение о предрасположенности души к постижению истины: «...всего легче и действеннее можно обратить человека: это вовсе не значит вложить в него способность видеть - она у него уже имеется, но неверно направлена, и он смотрит не туда, куда надо» [Там же, с.299]. Отсюда же и 
выводы Платона о том, что добродетели научить невозможно, что она достается лишь «по божественному уделу» [17, с.611], то есть не может быть учителей добродетели и учеников, нуждающихся в них. Но достаточно ли просто обратить взор человека «туда, куда надо», чтобы истина открылась ему? Платон отрицательно отвечает на этот вопрос, несмотря на то, что все же разделяет точку зрения божественной предрасположенности к занятиям философией ${ }^{1}$. Душа должна готовиться к обретению такого опыта, она не может вмиг сбросить с себя оковы пещерной жизни и обратиться к свету, поскольку такое обращение будет болезненным для нее. Философ отстаивает принцип природосообразности образования, нарушение которого приводит к результатам, абсолютно противоположным изначально поставленной цели - помочь душе выйти из варварского существования в мире теней. Если неподготовленную душу станут насильно тянуть к свету, ее сопротивление такому насилию будет только увеличиваться, она будет лишь убеждаться в том, что в мире теней больше правды, чем там, куда ее хотят направить. Кроме того, подчеркивает Платон, даже если бы и удалось вывести такую душу на свет, то глаза ее «были бы поражены сиянием» $[19$, с.296], и она не смогла бы различить ни одного предмета. Иными словами, Платон пытается показать, что душа должна созреть для восхождения в мир эйдосов и непосредственного общения с ними. Ее силы должны постепенно нарастать, у нее должны постепенно формироваться необходимые для этого способности. Поэтому душе необходима пропедевтика общения с идеальным миром.

Но какой же тогда должна быть эта пропедевтическая программа? Платон объясняет, что ее главная задача - сформировать привычку к свету: «Начинать надо с самого легкого: сперва смотреть на тени, затем на отражения в воде людей и различных предметов, а уж потом - на самые вещи; при этом то, что на небе, и самое небо ему легче было бы видеть не днем, а ночью, то есть смотреть на звездный свет и Луну, а не на Солнце и, его свет» [Там же]. Умение смотреть на тени и отражения вещей развивается благодаря тем «помощникам и попутчикам», к которым Платон относит искусство счета, геометрию, астрономию и математику: «Взятое в целом, занятие теми науками, о которых мы говорили, дает эту возможность и ведет прекраснейшее начало нашей души ввысь, к созерцанию самого совершенного в существующем» [Там же, с.316].

Нельзя не отметить того, что, в отличие от софистов, которые видели в математике лишь средство тренировки формального мышления или гимнастку для ума, Платон облагораживает цикл математических занятий, объясняя значимость решаемой ими задачи - приучать душу созерцать умопостигаемое «при помощи рассудка, а не посредством ощущений» [Там же, с.394]. Однако он все же постоянно подчеркивает, что рассудку

1Можно упомянуть рассуждения Сократа о том, что именно ему было дано некое «божественное знамение», при этом ранее, заявляет он, ни с кем такого не бывало [Там же, с.276]. 
нужно отдать то должное, которое соразмерно его возможностям, ограниченным допущениями и гипотезами, составляющим основу $\mu \alpha \theta \eta \dot{\mu} \mu \tau \alpha$. Так как эти искусства «будут сохранять их незыблемыми и не отдавать себе в них отчета», соответствующим им способом созерцания будет лишь сон промежуточное состояние между состоянием невежества, связанным только с ощущением и мнением, и полной просветленностью, которой адекватна разумная способность души: «...им всего лишь снится бытие, а наяву им невозможно его увидеть...» [Там же, с.317]. Остается тем не менее задать Платону вопрос о том, каким образом рассудок обращает себя к разуму, каким образом исследователь, погруженный в цикл математических занятий, вдруг начинает отдавать себе отчет в том, что он всего лишь спит. Как совершается его пробуждение и каким образом он переходит к тому состоянию, когда начинает «...смотреть уже на самое Солнце, находящееся в его собственной области, и усматривать его свойства, не ограничиваясь наблюдением его обманчивого отражения в воде или в других, ему чуждых средах» [Там же, с.297].

Может показаться, будто философ настаивает на том, что лишь божественным замыслом избираются немногие, кто оказывается способным на такое обращение, ведь, утверждает он, хоть и возможно, но крайне сложно не подвергнуться порче, живя в испорченном государстве. Но зачем тогда все же посвящать себя тому кругу занятий, которые с детства, как он заявляет, приучают душу смотреть в правильном направлении? Не является ли излишней вся эта пропедевтика, если сама по себе она не гарантирует ожидаемого результата, если решающим моментом его достижения все-таки оказывается воля божества? К тому же нам может показаться, будто Платон категорично заявляет о том, что переход от цикла математических занятий к той сфере, где душа уже не нуждается в образах или в предпосылках, но действует «посредством одного лишь разума» [Там же, с.316], осуществляется как отбрасывание или отрицание прежнего опыта, после чего диалектически, лишь «при помощи самих идей пролагает она себе путь» [Там же, с.292]. Но все же следует ли нам интерпретировать эту мысль так, будто новое состояние должно отрицать прежнее? Значит ли это, что весь тот путь, который проделала душа, поскольку он был связан с неясными основаниями, а не с самими эйдосами, оказывается излишним, и поэтому диалектика стоит особняком от всего остального цикла занятий?

Интересно обратить внимание на следующее: в оригинале текста процитированного отрывка мы встречаем причастие $\alpha v \alpha \iota \rho \tilde{\sigma} \sigma \alpha$, образованное от глагола $\alpha v \alpha i ́ \rho \omega$, который имеет двоякий перевод. С одной стороны, его переводят как «отклонять», «отвергать», «опровергать», «аннулировать», с другой же, - как «поднимать», «возвышать», «воодушевлять», «возносить». Учитывая все это, мы можем интерпретировать платоновские рассуждения о переходе души к подлинно свободному состоянию следующим образом: восходя к идеальному миру, она не отбрасывает свой опыт как некое бремя и груз, а, усматривая в нем его причастность к идеальному, опровергает лишь его конечные формы и тем самым возводит их 
ко всеобщему эйдосу. Такую активность, на наш взгляд, и следует понимать как действие в ней божественной силы или же как божественную силу в ней. Упуская эти аспекты платоновского понимания души, мы не понимаем природы ее активности, в связи с чем мы также не можем понять и веры Платона в достижимость идеального состояния, в реалистичность и завершенность описываемого им образовательного пути. Нам кажется, будто он наивен в своих рассуждениях. Однако Платон указывает на божественную активность души, которую она может постигать в себе. Ею является Эрос - «лучший помощник» [18, с.122] в стремлении к идеалу. «Эрос... становится символом любви человека к Благу», - рассуждает Йегер [Там же, с.191]. Интерпретируя мысль Аристофана, согласно которой человек ищет свою половину, желая вернуться к прежней цельности, он подчеркивает, что Эрос человека изначально направлен не на какие-то особенные черты, а стремится к завершенности и совершенству. Обрести вторую половинку не означает приобрести особенную часть: «Эрос не ищет, как это утверждал Аристофан, свою половину или даже целое, если под этим не понимается Благо или Совершенство» [Там же]. Иными словами, человек ищет себя как целое, а это значит, что он образовывается в возвышенной любви к самому себе, если под этим целым понимать присущее его природе всеобщее благо, которое ему остается внутренне постичь.

Как отмечает Йегер, данную мысль повторяет Аристотель, и это «чисто платоновский элемент» в его этике [13, с.303]: «...действительно, если кто всегда усерден в том, чтобы прежде всего самому совершать поступки правосудные, благоразумные или какие-то из тех, что так или иначе подобают добродетели, и вообще всегда оставляет за собою нравственную красоту, то никто не скажет, что этот человек “себялюбив", и не осудит его. А ведь именно такого можно посчитать в большей мере “себялюбом", ибо он уделяет себе самые прекрасные и первейшие блага и угождает самому главному в себе, во всем ему повинуясь; и как государство и всякое другое образование - это прежде всего его главнейшая часть, так и человек; выходит, что себялюбом [в высшем смысле] является в первую очередь человек, дорожащий этой частью себя и угождающий ей» [4, c.256].

Однако Аристотель, в отличие от Платона, на наш взгляд, уже далеко не мифически и потому более продуманно излагает идею образования души как путь ее энтелехийного развития, а его рассуждения о возвышенном себялюбии помогают нам глубже ее понять. В душе есть все, чтобы она могла стать собой. Ее целостность определена ее же цельностью, то есть собственным самовоплощением внутренне заложенной цели. Эрос души ее энергия и цель ее образования едины и взаимоопределены своей энтелехией. Душа не способна воплотить в себе не свою цель или то, чего в ней нет. Ее действительность определена ее возможностью, и ее энергия тождественна ее же собственной сути. Поэтому энтелехия души есть ее самообразование. Подлинное образование вообще не может быть чем-то иным, но только самообразованием. В этой связи Аристотель различает энтелехию мира вещей и энтелехию души: «Итак, там, где возникающее есть чтото другое помимо применения способности, действительность находится 
в том, что создается (например, строительство - в том, что строится, ткачество - в том, что ткется... <... ...а там, где нет какого-либо другого дела, помимо самой деятельности, эта деятельность находится в том, что действует (например, видение - в том, кто видит, умозрение - в том, кто им занимается...» [3, с.245-246]. Таким образом, себялюбие души как деятельность, направленная на саму себя, а не на внешний предмет, и есть обретение ею своей целостности и завершенности, поскольку любить себя значит образовываться в качестве собственного внутреннего предмета. Отсюда следует очень важный вывод: педагогика, сконцентрированная на том, чтобы вооружить душу набором способностей и умений, наполнить ее память разнообразными сведениями о мире и даже о ней самой, но не заботящаяся о познании душей собственной идеи, то есть не научившая ее духовному себялюбию, может прекратить свои старания, поскольку бесцельное существование души оказывается бесцельностью и неподлинностью педагогических усилий. Аристотель замечает: «А что движение находится в движущемся, это ясно, ибо оно его осуществление посредством того, что приводит в движение. А действие (energeia) того, что приводит в движение, не другое, [нежели у движущегося], ибо оно должно быть осуществлением того и другого; в самом деле, нечто может приводить в движение благодаря тому, что способно к этому, а приводит в движение благодаря тому, что действует, но деятельно оно по отношению к тому, что может быть приведено в движение, так что действие у обоих в равной мере одно...» [Там же, с.289].

Сказанное позволяет более точно сформулировать то, что Платоном было еще только намечено. Речь идет о единстве образовательного цикла и его результата, особенного содержания наук и их всеобщей формы. Аристотель придает этой мысли уже более ясный характер, объясняя, что «...мудрый знает все, насколько это возможно, не имея знания в отдельности о каждом предмете» [2, с.33], хотя тут же он называет божественной наукой не только ту, «которою скорее всего мог бы владеть Бог», но и науку «о божественных предметах», уточняя, что в искомой им науке сочетаются оба признака божественности [Там же, с.35]. П. Адо пытается показать, что именно Аристотель наилучшим образом раскрывает тот тип классификации, который характеризуется французским исследователем как «концептуальная пирамида» [36, с.202], представляющая собой внутреннюю специализацию философского знания, образующую иерархию наук. Платон же, подчеркивает он, противопоставляет метод математических наук диалектическому [lbid]. Поэтому философ не видит в пропедевтическом знании собственного содержания философии. И хотя Платон рассуждает о единстве особенных наук, подлинная философия для него пока еще представляет собой лишь его прообраз. Аристотель, напротив, рассуждает о божественном характере самого научного цикла, однако он не объясняет, как можно было бы постигать его не только в каждом отдельном моменте этой системы, но и в ее тотальности. Поэтому философ лишь различает теоретические дисциплины, которыми являются математика, физика и теоло- 
гия, и выстраивает их иерархию в соответствии со степенью умозрительности каждой из них, подчеркивая при этом, что самая теоретическая наука является «всеобщей в том смысле, что она первая» [2, с.200].

Адо противопоставляет аристотелевскому типу классификации наук тот, который осуществляют стоики: «Разделяя философию на логику, физику и этику, возможно и обращаются вновь к более ранней классификации. Но в то же время ей придают абсолютно новый смысл, как по причине содержания различных частей, так и по причине взаимосвязей, устанавливающихся между ними» [36, р.208]. Так, например, Диоген Лаэртский указывает на то, что стоики считают необходимым определять все предметы «...именно через логическое рассмотрение, даже если они принадлежат к области физики или этики, не говоря уже о логике [10, с.272]. При этом среди стоиков, поясняет он, все же существует различное понимание порядка соотношения частей философии. Вместе с тем Диоген также отмечает, что есть и те, кто вообще не отделяет друг от друга и даже «преподают их ... без разделения» [Там же, с.260]. А Цицерон утверждает, будто стоики сводят всю систему наук к предмету этики: «К тем же добродетелям, о которых идет спор, причисляют они диалектику и физику, называя и ту и другую добродетелями» [31, с.157].

Комментируя Хрисиппа, Плутарх рассуждает о «круженьи порядка [дисциплин]» стоической системы: «...это противоречие особенно заметно в устах человека, который, утверждая, что учение о природе есть начало учения о благе и зле, приказывает изучить его не прежде, но после последнего. <...> ...Хрисипп враждует с собой, приказывая принимать учение о богах последним и завершающим на том основании, что завершение называется посвящением, и опять же вместе с тем где-то говорит, что часть богословия должна браться в числе первых предметов [для изучения]. От порядка ничего не останется, если все части будут браться во всех; но, что важнее, он приказывает не начинать с богословия и затем переходить от него к учению о добре и зле, но, положив вначале это [этическое] учение, они берут и часть теологии как участвующую в ней по случаю, а затем переходят от этики к собственно богословию, хотя потом он [Хрисипп] говорит, что нет ни начала, ни входа помимо богословия» [22, с.137-138].

На наш взгляд, такое «круженье» является ничем иным, как противоречием между стремлением духа изложить систему знания и его тенденцией проследить путь ее развития, показать этапы ее возникновения. Это - путь воспитания духа, требующего для себя понимания порядка бытия и его духовного постижения: «Стоики слишком чувствительны к этому педагогическому повелению» [36, p.215]. Их внимание к философской активности человека указывает на то, что истина не воспринимается как нечто готовое и открывающееся непосредственным образом. В одном из комментариев к фрагментам текстов ранних стоиков, посвященных делению философии, А.А. Столяров описывает версию нестандартного, противопоставленного общепринятой последовательности «логика-физика-этика», расположения частей философии, якобы введенного Хрисиппом, в котором этика находится между логикой и физикой «на том основании, что из 
пропедевтических соображений научение лучше всего вести от менее сложного к более сложному и важному и подводить к теологии, завершая, таким образом, все обучение богопознанием» [29, с.22]. Столяров делает очень важный вывод, согласно которому стоики описывают иерархию наук «исключительно в целях пропедевтики», но при этом мыслят все части философии «в органическом единстве» [Там же, с.21].

Таким образом, история античной мысли достигает того момента, когда не только ставится вопрос об истине вообе и о том, как она учреждает себя в системе наук, но и о том, как душа открывает для себя эту систему, в каком порядке она осваивает ее моменты, каким образом должен быть систематизирован опыт ее совершенствования. Нельзя не согласиться с Адо в том, что хотя Платон и был озадачен проблемой душевного прогресса, все же он дает еще только набросок его программы в «Государстве», описывая цикл занятий будущих философов-правителей. При этом путь восхождения души к истине представлен им метафорически - либо как ее выход из пещеры на свет, либо как посвящение в элевсинские таинства, символизирующее непосредственность и простоту ее постижения, к которому не должны примешиваться иные знания. Аристотель же в своих работах вообще говорит об этом крайне мало. Так, в Метафизике, например, он делает краткую ремарку о необходимости знакомства с аксиомами аналитики до перехода к истинам первой философии [2, с.112]. А в Никомаховой этике он всего лишь констатирует, что юноша - «неподходящий слушатель науки о государстве», и к ее освоению ему необходимо специально готовиться. Подготовка же эта должна состоять в получении всестороннего образования: «...[добродетельный] в частном и образован применительно к частному, а вообще [добродетельный] образован всесторонне» $[4$, c.55].

Стоики, утверждает П. Адо, первыми начинают рассуждать о философской педагогике, рассматривая взаимопричастность частей философии, «одновременные занятия которыми образуют мудрость» [36, р.215]. При этом он делает очень важное замечание, касающееся специфики классификации наук в целях философского образования: эта классификация должна отражать уже не систему собственно философских наук, а «入о́үо философского воспитания» [Ibid]. Таким образом, мы наконец обнаруживаем, что именно в контексте размышлений о вопросах философского образования античные авторы начинают активно использовать термин

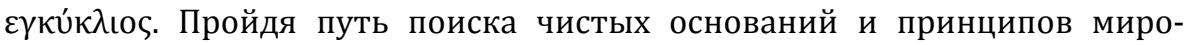
устройства, а также той науки, содержание которой они образуют, античный дух должен обратить внимание на то, как это содержание открывается сознанию, как оно усваивается им, какие душевные силы и способности задействованы в этом процессе. Вот почему он идёт «окольным» путем к вопросам философского образования. Именно тогда, когда возникает потребность исследовать образовательную систему философствующей души, требуется понятие, с помощью которого мысль постигает и опреде-

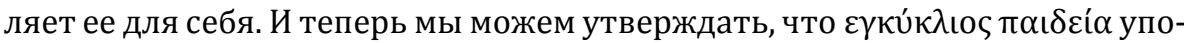


требляется неслучайно, ведь в этот период развития античной мысли сознание стремится определить истину, на которую оно раньше только указывало и которую оно воспринимало лишь как нечто самодовлеющее, в качестве истины для себя или того, к чему оно идет исключительно благодаря собственной созерцательной активности. Иными словами, сознанию, уже знающему истину в качестве «неподвижного перводвигателя», теперь открывается оно само.

Вот что Гегель пишет о состоянии духа этого периода: «Не только разум, но и все остальное должно быть некоим мыслимым, т.е. должно быть в качестве субъективного моей мыслью. <...> ...мышление и мыслящий, следовательно, непосредственно связаны между собою» [8, с.303]. Теперь сознание исследует вопрос о содержании собственной деятельности, благодаря которой истина выступает перед ним и открывается ему «...субъект, следовательно, есть то, о чем следует заботиться. Субъект ищет для себя некоего принципа своей свободы, внутренней невозмутимости» [Там же]. И то, как решается эта задача, определяет развитие понятия

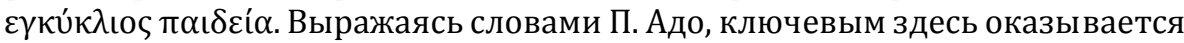
конфликт между логическим и педагогическим аспектами духовного прогресса [36, p.216]. Иначе его можно было бы обозначить вопросом: тождественен ли логос души, актуализирующийся в ней благодаря ее образовательным усилиям, божественному логосу? В зависимости от того, как он решался тем или иным мыслителем, уточнялось и назначение самого образовательного процесса. Если полагали, что он не обеспечивает перехода к истине, которая в этой связи остается чем-то потаенным для субъекта, то и круг такого образования считали бесполезным, о чем, например, согласно Диогену Лаэртскому, заявлял Зенон. Аристипп же сравнивал тех, кто предавался «обычному кругу знаний» и пренебрегал философией, с женихами Пенелопы, завладевшими ее рабынями, но не добившимися брака с самой госпожой [21, с.121]. И у Аристона, по словам Диогена, имелась похожая аналогия. Тех, кто посвящал себя широкому кругу занятий, он сравнивал с Одиссеем, который, «спустившись в Аид, встретил и увидел там почти всех мертвых, но не лицезрел самой их царицы» [Там же].

В Письме LXXXVIII Луцилию Сенека указывает, что единственное и подлинное, по его мнению, искусство называется мудростью. Остальные же он считает «пустяками, годными для детей»: «Все эти вещи нужно не все время учить, а однажды выучить» [23]. Сам по себе, продолжает Сенека, цикл этих искусств не учит добродетели и поэтому является бесполезным. Но почему же тогда он существует и почему все же им занимаются? Сенека отвечает на данный вопрос следующим образом: «Дело не в том, что они (искусства. - И.3.) могут дать добродетель, а в том, что они подготавливают душу к ее восприятию» [Там же]. Ссылаясь на классификацию Посидония, Сенека выделяет класс свободных искусств (artes liberalis), которые отличаются от ремесел (будничные искусства), а также от искусств, направленных на развлечение (потешные искусства). Кроме того, свободные искусства отличаются и от так называемых детских - тех, которые носят инструментальный характер и, как уточняет Сенека, «у греков называются 
$\varepsilon \gamma \kappa \cup \kappa \lambda \iota เ »\left[\right.$ Там же] ${ }^{1}$. Они имеют нечто общее с философскими науками и потому стремятся примкнуть к ним. Однако поистине свободные искусства, образующие, по словам Сенеки, части философии, предметами которых являются природа, нравы и человеческий разум, пользуются «услугами» детских или энциклических искусств, например, геометрии, не входящих в класс философских.

Аналогичным образом рассуждают Крантор и Ксенократ [1, с.334]. Плутарх также затрагивает этот вопрос, утверждая о том, что свободнорожденный ребенок должен владеть знаниями из разнообразных обла-

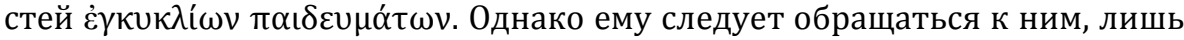
чтобы «испробовать их», но «философию он должен почитать больше всех остальных» [37, р.35].

Таким образом, не столько содержание, сколько решение пропедевтических задач, направляющее душу к добродетели, определяет ценность таких искусств. Они «...облегчают путь к ней», - говорит Сенека. О том, что изучение энциклических искусств представляет собой путь к добродетели говорит и Стобей: «Что касается любви к музыке, грамоте, конному искусству или искусству разведения собак и вообее всех прочих так называемых общеобразовательных ${ }^{2}$ искусств, то они называют их склонностями

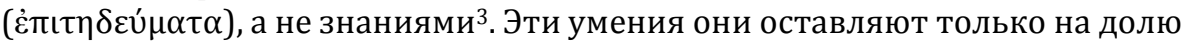
нравственно-достойных состояний и, соответственно, утверждают, что любителем музыки или словесности может быть только мудрец, и то же самое относится ко всем прочим умениям. А что касается самой склонности, то они определяют его так: “путь, который через искусство или его часть ведет к добродетельным вещам"» [30, с.114].

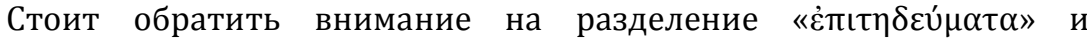

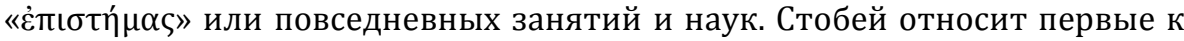
энциклическим и, согласно Адо, считает их свободными, поскольку ими мог заниматься только свободный человек, имеющий досуг или свободно распоряжающийся своим временем. Сенека же называет философские науки свободными, руководствуясь совершенно иными основаниями, - не принципом элитарности образования, а самим предметом, его причастностью к добродетели. Не то, кто занимается науками, а то, что составляет их предмет, определяет данный статус. Адо делает интересное пояснение, согласно которому в такой классификации детские искусства «отличает от занятий философией не столько их содержание, сколько цель» [1, с.331]. В

${ }^{1}$ Адо подмечает, что Посидоний называет их pueriles, поскольку, «...по его мнению, единственная научная деятельность, достойная взрослого человека, - занятие философией или изучение наук, чтобы впоследствии заняться философией» [1, с.331] (331). А Сенека полагает, что цикл искусств, традиционно характеризуемых самими римлянами как liberalis, следовало бы считать подготовительными и потому детскими, как это делали греки, строго противопоставляя их подлинно свободной науке.

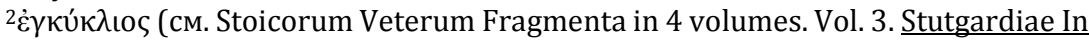
aedibus B.G. Tuebneri, MCMLXIV, p. 72).

${ }^{3} \dot{\varepsilon} \pi ı \tau \eta \dot{\mu \alpha \varsigma}$ (см. там же). 
данном случае речь идет об образовательной цели. С этой точки зрения философия должна считаться совершенно бесполезной наукой, ведь она существует ради истины, но не ради образования. Поэтому во всей системе наук она сама - цель. Вместе с тем философия имеет слуг в виде энциклических занятий, которые предназначены для того, чтобы подготовить душу к постижению истины. В контексте такого рассмотрения они являются самоценными и могут быть названы свободными. Ведь сознание ориентировано на них как на некую цельную и идеальную образовательную программу. Хотя оно и интересуется теми основаниями, благодаря которым усваивает предмет этих наук, все же ему пока еще не удается открыть в себе такую же цельность, то есть зрелость, благодаря постижению которой оно познало бы себя как источник круга собственного образования. Поэтому пока индивид будет называть его детским, полагая, будто такое образование предназначено именно для того, чтобы сделать его взрослым.

Ввиду того что сознание находит свою идею не в себе, а в ином, будет сохраняться водораздел между целью и способом ее достижения, между методом и результатом, между энциклическими занятиями и философской наукой. До тех пор, пока предмет последней будет доминировать в иерархии остальных наук, пока сознание не найдёт в самом себе той свободы, которой, согласно его «детским» представлениям, обладает он, ее связь с ними будет определяться случайным образом, поэтому и классификация пропедевтических занятий будет произвольной. А.-И. Марру прекрасно демонстрирует такую ситуацию, приводя примеры различных ее версий, появляющихся в различные периоды Античности [35, р.216]. Так, например, он показывает, что Гераклид Понтийский относит к их числу грамматику, риторику, диалектику, музыку и геометрию. Аркесилай грамматику, красноречие, диалектику и математику. Филон Александрийский - грамматику, риторику, диалектику, музыку, геометрию и астрономию. Сенека - грамматику, музыку, геометрию, арифметику, астрономию. Ориген - грамматику, риторику, геометрию, музыку, астрономию. Порфирий - цикл искусств, позже представленных как единство тривиума (грамматика, риторика, диалектика) и квадривиума (арифметика, музыка, геометрия, астрономия) под общим названием семи свободных искусств.

В конце концов, не найдя для себя надежной образовательной про-

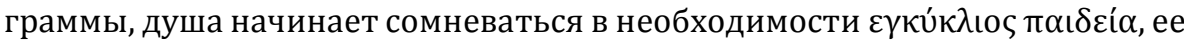
внимание привлекают практики непосредственного обращения к истине. Афиней ссылается на поэта Миртила, восхваляющего Эпикура за то, что тот, «...сам не имея общего образования ${ }^{1},<\ldots>$ благословляет всех, кто так, как он, приступает к философии <...> “Счастлив ты, что приступаешь к философии, чистый от всякого образования”» [5, с.290]. А Плутарх пишет о македонском царе Филиппе, отце Александра Македонского, который «...не решался полностью доверить обучение и воспитание сына учителям музыки и других наук, входящих в круг общего образования...» [21]. Однако он также пишет и об упреке, высказанном Александром Аристотелю

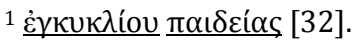


за то, что тот предал огласке учения, которые, по его мнению, должны передаваться втайне и устно, но не должны быть общим достоянием: «Я хотел бы превосходить других не столько могуществом, сколько знаниями о высших предметах». Аристотель же, успокаивая Александра, дал ему заверение в том, что такое знание «...предназначено для людей образованных и совсем не годится ни для преподавания, ни для самостоятельного изучения» [Там же].

Таким образом, с одной стороны, энциклические науки воспринимаются как общедоступные, однако, согласно изложенным взглядам, общедоступное знание само по себе не может помочь человеку выделиться из толпы и достичь сакрального знания. С другой стороны, для его понимания все же необходимо быть образованным, то есть уже иметь некоторую душевную подготовку. Иными словами, мы встречаем две противореча-

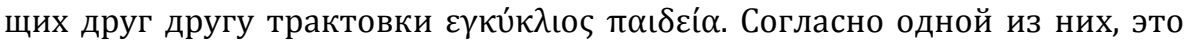
цикл научного образования, «подчиненного», выражаясь словами Адо, философии. Согласно другой - это курс базового (вульгарного) образования, не связанного с ее задачами. Однако античный дух не может задержаться на данной точке зрения, поскольку пронизан поиском цельности и завершенности во всем, в связи с чем он обращается к содержанию частных дисциплин, стремясь открыть в их специфической природе всеобщее предназначение. Подобное вопрошание мы встречам у античных ученых, специализирующихся на изучении того или иного особенного предмета. Например, Витрувий утверждает, что образование архитектора должно быть всесторонним. Однако, поясняет он, речь идет не о наполнении памяти сведениями из различных наук, но об усмотрении единой связи между ними: «предметы всех отраслей знания имеют много общего и соприкасаются друг с другом <...> Ибо всестороннее образование является как бы единым телом, состоящим из отдельных членов. Поэтому те, кто с юных лет снабжаются разносторонними сведениями, обнаруживают во всех науках одинаковые признаки и взаимную связь всех отраслей образования, благодаря чему постигают всё с большею легкостью» [6, с.19]. Как раз неосуществимым, подчёркивает он, является стремление тех, кто занимается отдельным предметом обособленно от других занятий, довести его изучение до совершенства. Ведь кроме практической части в каждой науке имеется теоретическая, объединяющая ее с остальными, отказ от которой или игнорирование которой как раз и мешает ученому стать подлинно образованным человеком: «...каждое отдельное искусство состоит из двух частей: практики и теории. Одна из них, именно выполнение на практике, присуща знатокам, другая, т. е. теория, является достоянием всякого образованного человека; например, о биении пульса и движении стоп рассуждают и врачи, и музыканты; но если понадобится лечить рану или спасти от опасности больного, то за это возьмется не музыкант, а это будет настоящее дело врача. Точно так же не врач, а музыкант будет играть на органе для услаждения слуха приятными напевами» [Там же, с.20]. 
Нельзя не упомянуть и медика Галена, который в трактате «0 том, что наилучший врач есть также философ» негодует по поводу ограниченности большинства врачей, слишком узко рассматривающих свой предмет, не понимающих, что «астрономия и, очевидно, предшествующая ей по необходимости геометрия в немалой степени содействуют медицине» [7, c.93]. Заимствуя у стоиков их классификацию наук, Гален также объясняет, что невозможно быть хорошим врачом и при этом не быть философом: «Ибо если для того, чтобы изучить природу тела, различия болезней и показания к лечению, ему подобает упражняться в логическом умозрении, а чтобы трудолюбиво предаваться этому занятию - презирать деньги и упражняться в воздержании, то он обладает всеми частями философии логикой, физикой и этикой <... И конечно, если философия необходима врачам в начальном обучении и в последующей практике, то очевидно, что всякий, кто будет совершенным врачом, тот будет также философом» [Там

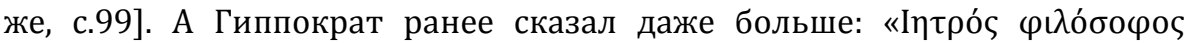
íoó $\theta \varepsilon \varsigma{ }^{1}$, имея ввиду, что «...должно, собравши все сказанное в отдельности, перенести мудрость в медицину, а медицину в мудрость <...> Да и немного в самом деле различия между мудростью и медициной, и все, что ищется для мудрости, все это есть и в медицине, а именно: презрение к деньгам, совестливость, скромность, простота в одежде, уважение, суждение, решительность, опрятность, изобилие мыслей, знание всего того, что полезно и необходимо для жизни, отвращение к пороку, отрицание суеверного страха пред богами, божественное превосходство» [9, с.111].

Таким образом, разнообразие душевных способностей и качеств определено разнообразием наук, занятия которыми направлены на целостное формирование души. Поэтому такой процесс уже понимается не просто как внешняя пропедевтика, подготавливающая к овладению сакральным знанием, но как целостное образование человека как такового. Все части души в едином устремлении направлены единым циклом наук к ее совершенству, и прохождение особенных этапов, знакомство с особенностью каждого предмета во взаимопроникновении с другими постигается как естественный и необходимый путь ее развития. По этому поводу

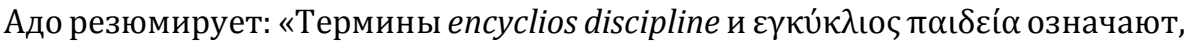
таким образом, курс наук, объединенных методикой и структурой, который следует пройти до конца, чтобы получить полное образование; это в каком-то смысле «цикл», и науки, его составляющие, могут, в свою очередь,

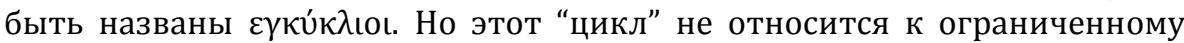
числу наук, как это будет, например, с “семью искусствами”, но соответствует идее внутреннего единства и законченности» [1, с.325]. И все же энциклический путь не есть путь доступного многим образования. Это - путь подлинно научного познания или путь ученого. Комментируя высказывания Квинтилиана о том, что тот нацелен воспитать «идеального и совершенного», а не «среднего», ритора, Адо пишет примерно об этом же: «...вы-

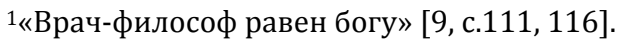




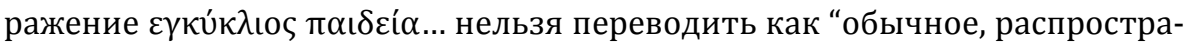
ненное образование”, учитывая даже, что это “обычное” образование было предназначено лишь для меньшинства; скорее следовало бы переводить это выражение как “всесторонняя культура”» [1, с.324-325]. Это такая культура, благодаря которой, с одной стороны, ученый-специалист перестает быть просто специалистом, «техником» или «эпистэмщиком» [25] и, открывая в себе философа, становится подлинным профессионалом. Как утверждает Гален, все науки, хотя каждая из них и определена особым образом, смотрят на одного бога, образуя вокруг него иерархию концентри-

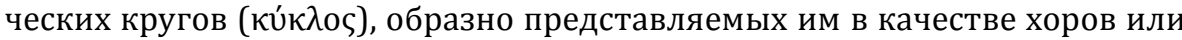
хороводов [1, с.327].

Стоит отметить, что образ хоровода использует уже Платон: «Искусство хоровода в целом состоит из песен и плясок <..> Поэтому хорошо воспитанный человек должен уметь прекрасно петь и плясать» [16, с.118]. A.A. Тахо-Годи, комментируя данный эпизод, отмечает, что, согласно представлениям древних, участие в хороводе имеет воспитательную силу, так как с ним связано развитие чувства ритма и чувства гармонии, формирующих не только тело, но и душу человека [Там же, с.605]. А Р.Л. Фоулер утвер-

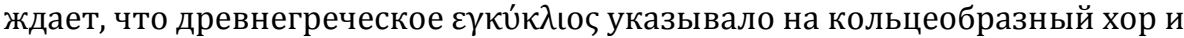
что исполнение традиционных гимнов и танцев было одной из важнейших частей образования каждого свободного ребенка: “"непричастный хору” значит “необразованный” или “невоспитанный” » [33, с.15].

Но и в позднеантичный период Синезий использует аналогичный образ: «Музы составляют хор благодаря схождению вместе; ни одна из них не отделяется от других, на пиру богов ни одна из них не выпячивает своего особого дела и не имеет у людей ни отдельного алтаря, ни отдельного храма» [25]. При этом, продолжает он, прежде чем перейти к мистериям Муз, необходимо пройти круг посвящения, необходимо познакомиться с различными науками. И несмотря на то, что их предметы некоторые называют «низшими ума вещами», тем не менее, поясняет Синезий, они «...космизируют то око [души, о котором говорил Платон], избавляют его от гноя, пробуждают его и потихоньку приучают видеть [свойственные ему] вещи, так что через некоторое время оно обретает дерзновение взглянуть и на более достойное зрелище, больше уже не щуриться, взглядывая на солнце» [Там же]. При этом философ, которого он представляет в образе Аполлона, выполняет то, что свойственно лишь ему одному - объединяет науки так, чтобы они стали хором. Поэтому, с одной стороны, такая задача возвышает его над ним, с другой, «Аполлон [всегда] приходит и находится с хором Муз [, а не с некоторыми из них] <...> поет то вместе с Музами, то сам по себе [и это, нужно полагать, как раз и есть его тайная и священная песня» [Там же].

Синезий противопоставляет этот путь образования тому образу жизни, который вели киники и монахи, стремясь достичь цели одним лишь прыжком к ней, без какого бы то ни было развития и последовательного продвижения. Этот непосредственный скачок Синезий сравнивает с вакхическим исступлением, называя его «прыжком безумца, одержимого богом». Философ же «всегда внимательнее рассматривает “посредующее”. 
Ибо он подготавливает ступени на пути восхождения, так что [его не просто возносит Высшее, но] он делает нечто и самостоятельно (курсив мой. - И.В.) <... Таким образом, из тех, кто движется этим вот [философским] путем, большие, пожалуй, достигают цели, ибо они стремятся и действуют согласно природе». [Там же]. Подобным же образом и Император Юлиан в его речи против Гераклея противопоставляет энциклическое образование «укороченному» пути киников, иронично заявляя о том, что выбранный им путь гораздо короче [39, с.151, 153]. А Филон Александрийский рассуждает о том, что прежде необходимо свернуть «с неровной и каменистой тропы», чтобы встать на широкий путь и далее уже идти по нему уверенным и твердым шагом. Иными словами, прежде чем обратиться к мудрости, следует получить энциклическое образование [27].

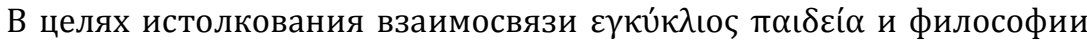
Филон обращается к ветхозаветным образам. Агарь, служанка Сары, олицетворяет собой подготовительное образование. Сара, супруга Авраама, символизирует либо саму философию, либо ее предмет - мудрость (Филон не дает строгого определения данному образу). Авраам же - образ философа или ума, стремящегося соединиться с мудростью. Но прежде он должен пройти подготовку, то есть соединиться с Агарью, о чем его просит сама Сара: «"Войди же, - говорит она, - к служанке моей”, среднему образованию, состоящему в научении средним и общим наукам, “чтобы прежде ты родил себе детей от нее”, ведь потом ты сможешь извлечь пользу и из связи с госпожой для рождения законных детей» [27]. Таким образом, Фи-

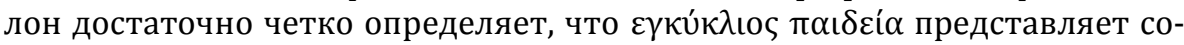
бой систему пропедевтического образования или «круг подготовительных знаний», позволяющий Аврааму достичь единства с Сарой: «обыкновенно великим предметам предпосылаются и великие вступления» [27]. В то же время неопределенность ее образа указывает на проблему определения роли философии в завершении цикла подготовительных наук, то есть вообще в завершении образовательного цикла души: «И подобно тому как науки, составляющие круг общего образования, помогают восприятию философии, так и философия - приобретению премудрости. Ибо философия это занятие премудростью, премудрость же - знание о божественном и человеческом и о причинах того и другого. И вот, пожалуй, выходит, что как мусические науки - рабы философии, так философия - раба премудрости» [27].

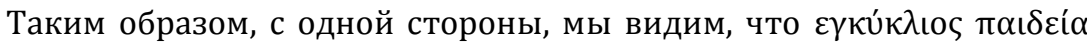
рассматривается как естественный, необходимый и сообразный природе души метод, с помощью которого она возводит себя к божественному порядку. Такое образование является ее разумным и последовательным саморазвитием, каждый особенный этап которого открывает свою сопричастность божественному содержанию и тем самым стремится замкнуть весь этот общий круг. Однако, постигая единство Муз или божественный смысл философской пропедевтики, античный дух все же пола-

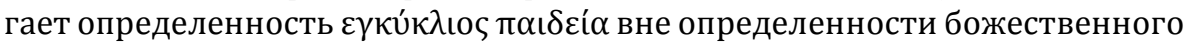


предмета, то есть пока лишь как его средство. «Аполлон» античности находится между этими двумя определенностями, а потому остается не проясненной логика образования души в ее соотношении с предметным содержанием $\varepsilon \gamma \kappa u ́ \kappa \lambda \iota \varsigma ~ \pi \alpha เ \delta \varepsilon i ́ \alpha$ и мудростью как абсолютной целью. Ввиду сказанного стоит вспомнить описание Плотином трех темпераментов, которыми души отличаются друг от друга в силу своих природных склонностей. Когда речь идет о такой образовательной цели, как мудрость, то, руководствуясь этой теорией, Плотин констатирует, что музыканты и рожденные любить требуют для себя больших педагогических усилий, а именно, требуют разъяснения философских истин, в отличие от философа, который, как он поясняет, хотя и нуждается в некоторой поддержке, точнее, в том, чтобы ему указали верный путь, тем не менее уже «...самой природой предназначен [для Высшего], и, образно говоря, “окрылен”, он не нуждается в отделении, как другие, он уже начал движение к Высшему... <...> ...он - кто уже по природе [своей] давно был свободен. Ему должна быть преподана математика ради подготовки [к философии] и [приобретения] веры в бестелесное - он усвоит все это легко, будучи естественно расположен к наукам; будучи от природы добродетельным, он должен придать своим добродетелям совершенство, и после математики ему должна быть преподана диалектика, которая и сделает его всецело диалектиком» [20, с.143]. Плотин также уточняет: невозможно перейти к диалектике, не совершенствуя более низкие формы природных добродетелей, которые, по его словам, могут появиться либо первыми, либо одновременно с высшими, и тем не менее, «...скорее, когда природные задатки уже существуют, обе [т. е. мудрость и природная добродетель] приходят к совершенству: когда развивается одна, она ведет к совершенству и другую.» [20, с.147]. Вместе с тем, несмотря на все это образовательное движение, те исходные принципы, которые необходимы для занятий диалектикой, согласно Плотину, душа не сама создает, а внешне воспринимает от Ума.

Очевидно, что философ стремится к постижению божественного смысла образовательного процесса души, в ходе которого ради достижения абсолютной цели развиваются все ее способности. Однако это развитие лишь подводит к моменту лицезрения Бога, после чего она должна оставить весь свой опыт и преодолеть саму себя, выйти за свои пределы, то есть вообще уже не столько созерцать, уточняет Плотин, ведь созерцание сохраняет двойственность, сколько войти в экстатическое состояние, отождествляющее ее с предметом созерцания. А этот переход есть «превращение себя в нечто совершенно простое и чистое». Можно даже резюмировать эту мысль словами А.А. Тащиана о том, что «...античная мысль была начальным этапом в развитии философского понятия: именно в эту эпоху реализуется первое отрицание конечного характера человеческого опыта и все особенное возводится в форму непосредственной (абстрактной) всеобщности. Как следствие - все эмпирическое множество как юдоль преходящей чувственной конечности может быть сохранено лишь при условии его возгонки в «сверх-сущее» единство интеллектуального мира. 
Насколько последний является действительным, это - общий вопрос об ограниченности и судьбе античной культуры» [26, с.19-20].

Но тогда какое значение имел путь образования души, если в конце концов она должна упроститься в единстве с Богом? Ведь если оставить этот момент без разъяснений, то возникает впечатление, будто она должна обезличиться, раствориться и исчезнуть в нем. И если все-таки речь идет о пропедевтике такого результата, то требуется прояснить или сделать понятным, как в связи с ней определяет себя единство божественной природы и как в нем можно было бы постигать ее особенное значение. Вместе с тем античная мысль «застревает» в колебании между хором Муз и мудростью как предметом философского познания, постигая сопричастность философской науки каждой из сторон, но не делая умозаключения об их единстве. Даже дух новой эпохи сразу не заметит этого противоречия и, напротив, со временем прочно укрепит себя в противопоставлении античной образованности откровения божественной мудрости.

\section{References}

[1] Адо И. Свободные искусства и философия в античной мысли / пер. Е.Ф. Шичалиной, ред. М. В. Асмуса, А. И. Любжина. М.: Греко-латинский кабинет Ю.А. Шичалина, 2002.

[2] Аристотель. Метафизика. Переводы. Комментарии. Толкования / Пер. и комм. А.В. Кубицкого. СПб.: Алетейя, 2002; Киев: Эльга, 2002.

[3] Аристотель. Сочинения в четырех томах. Т.1 / Ред. В.Ф. Асмус. М.: «Мысль», 1976.

[4] Аристотель. Сочинения в четырех томах. Т. 4 / Пер. с древнегреч.; общ. ред. А.И. Доватура. М.: Мысль, 1983.

[5] Афиней. Пир мудрецов / пер. Н.Т. Голинкевича. М.: Наука, 2010.

[6] Витрувий. Десять книг об архитектуре. Издательство: Архитектура-С, 2006.

[7] Гален. О том, что наилучший врач есть также философ / Историко-философский ежегодник. М.: Канон, 2012.

[8] Гегель Г.В.Ф. Лекции по истории философии: в 3 кн. Кн. 2 / ред. Н.А. Никитина; вступ. ст. К.А. Сергеева, Ю.В. Перова. СПб.: Наука, 2001.

[9] Гиппократ. Избранные книги / пер. с гр. В.И. Руднева. Госиздат биологической и медицинской литературы, 1936.

[10] Диоген Лаэртский. О жизни, учениях и изречениях знаменитых философов / пер. М.Л. Гаспарова, ред. А.Ф. Лосева. М.: Мысль, 1986.

[11] Диодор Сицилийский. Историческая библиотека / URL: http://simposium.ru/ru/node/9550.

[12] Йегер В. Пайдейя. Воспитание античного грека. Том 1 / пер. с нем. М.Н. Ботвинника. М.: Греко-латинский кабинет Ю.А. Шичалина, 1997.

[13] Йегер В. Пайдейя. Воспитание античного грека (эпоха великих воспитателей и воспитательных систем) / пер. с нем. А.И. Любжина. М.: Греко-латинский кабинет Ю.А. Шичалина, 2001.

[14] Марру А.-И. История воспитания в античности (Греция) / Пер. с фр. А.И. Любжина, М.А. Сокольской, А.В. Пахомовой; ред. А.И. Любжин. М.: Греко-латинский кабинет Ю.А. Шичалина, 1998.

[15] Мейдер В.А. Пайдейя и алетейя: Очерки философии образования: сборник статей / В.А. Мейдер, Е.А. Громова. М.: Флинта, 2014.

[16] Платон. Законы / Сочинения в 3 томах. Т.3. Ч.2. М.: Мысль, 1971.

[17] Платон. Менон / Собрание сочинений в 4 т. Т.1. М.: Мысль, 1990. 
[18] Платон. Федон. Пир. Федр. Парменид. М.: Мысль, 1999.

[19] Платон. Филеб. Государство. Тимей. Критий. М.: Мысль, 1999.

[20] Плотин. Первая эннеада / Пер., вступ. ст., коммент. Т.Г. Сидаша, Р.В. Светлова. СПб.: Издательство Олега Абышко, 2004.

[21] Плутарх. Александр и Цезарь / URL: http://lib.ru/POEEAST/PLUTARH/plutarkh1_2.txt.

[22] Плутарх. Сочинения / Пер. с древнегреч. Т.Г. Сидаша. СПб.: Изд-во С.-Петерб. унта, 2008.

[23] Сенека Л.А. Нравственные письма к Луцилию / URL: http://psylib.org.ua/books/senek03/txt088.htm.

[24] Симон К.Р. Термины энциклопедия и свободные искусства в их историческом развитии / URL: http://rus.1september.ru/article.php?ID=200103404.

[25] Синезий Киренский. О жизни по Диону / Трактаты и гимны // URL: https://azbyka.ru/otechnik/Sinezij_Kirenskij/traktaty-igimny/5.

[26] Тащиан А.А. Метафизика образования духа в философии Аврелия Августина // Вестник Русской христианской гуманитарной академии. № 1. Т. 16. 2015. С. 1831.

[27] Филон Александрийский. О соитии ради предварительного обучения / Толкования Ветхого Завета // URL: http://krotov.info/acts/01/joseph/filon_01.htm.

[28] Фрагменты ранних греческих философов. Часть I / пер. А.В. Лебедева. М.: Наука, 1989.

[29] Фрагменты ранних стоиков. Т. 1 / пер. А.А. Столярова. М.: Греко-латинский кабинет Ю.А. Шичалина, 1998.

[30] Фрагменты ранних стоиков. Т. 3, ч. 1 / пер. А.А. Столярова. М.: Греко-латинский кабинет Ю.А. Шичалина, 2007.

[31] Цицерон М.Т. О пределах блага и зла. Парадоксы стоиков / пер. Н.А. Федорова. М.: Издат. центр Российского государственного гуманитарного ун-та, 2000.

[32] Athenaeus. The Deipnosophists / URL: http://www.perseus.tufts.edu/hopper/text?doc=Perseus:text:2008.01.0405:book=13:chapter=53\&highlight=paidei\%2Fas.

[33] Fowler R.L. Encyclopaedias: Definitions and Theoretical Problems / Pre-modern Encyclopaedic Texts: Proceedings of the Second Comers. - Groningen, 1996, pp. 3-30

[34] Jaeger W.W. Humanism and Theology Aquinas Lecture. Marquette University Press, 1943.

[35] Marrou H.-I. Saint Augustin et la fin de la culture antique. Paris: De Boccard, 1938.

[36] Hadot P. Les divisions des parties de la philosophie dans l'Antiquité / Museum Helveticum. Vol. 36. 1979.

[37] Plutarch. The Education of Children / Plutarch`s Moralia in 14 vol. Vol. 1. London: William Heinemann, New York: the Macmillan Co, MCMXXVII.

[38] Stoicorum Veterum Fragmenta in 4 volumes. Vol. 3. Stutgardiae In aedibus B.G. Tuebneri, MCMLXIV.

[39] The Works of The Emperor Julian in Three Volumes. Vol. II. London: William Heinemann, New York: the Macmillan Co. MCMXIII. 